\title{
SUSTAINABLE MANAGEMENT OF BRACKISH KARST SPRING PANTAN (CROATIA)
}

\author{
TRAJNOSTNO UPRAVLJANJE BRAKIČNEGA KRAŠKEGA IZVIRA \\ PANTAN (HRVAŠKA)
}

\author{
Ivana FISTANIĆ
}

\begin{abstract}
UDC 556.3(497.5 Pantan)

Ivana Fistanić: Sustainable management of brackish Karst spring Pantan (Croatia)

Pantan area is situated in the central part of the eastern Adriatic coast near town Trogir. It presents inseparable unit consisting of Pantan spring, river course with surrounding swamp area and sea coast. Particularity of the area is swamp which is unique example in this part of the eastern Adriatic coast mostly characterized by dry karst areas. Main characteristic of the spring is periodical salinity during the year with the highest salinity during summer months. Spring presents potential drinking water source under consumption that salinization problem is solved. Unfortunately due to bed watershed management water quality of Pantan spring and environment of Pantan area is highly devastated. Today Pantan area presents an example of not preserving balance between natural resources on karst and human interventions in watershed area. All future measures should be directed on rehabilitation and further protection of this valuable karst environment. Paper gives overview of the state of the spring as well as proposed measures of sustainable management directed to the preservation of this distinct karst ecosystem. As the basis for analyzing the inter-related factors that impact on the environment, DPSIR framework is used. This framework provide rational and clear guideline for analyzing the influence of pressures derived from human activities on natural environment, and the way they are changing state of the environment. Results of the analyses showed that DPSIR framework is adequate tool to shape and implement sustainable development strategy for the Pantan area. It is evident that in this process is extremely important to take into the consideration vulnerability of the karst.
\end{abstract}

Keywords: brackish karst spring, integrated management, DPSIR concept, Pantan, Croatia.

\begin{abstract}
Izvleček
UDK 556.3(497.5 Pantan) Ivana Fistanić: Trajnostno upravljanje brakičnega kraškega izvira Pantan (Hrvaška)

Območje izvira Pantan se nahaja v centralnem delu vzhodne jadranske obale v bližini mesta Trogir. Gre za neločljevo celoto, sestavljeno iz izvira Pantan, površinskega vodotoka z okoliškim močvirjem in obalnega pasu. Posebnost območja je močvirje, edino v tem delu Jadrana, kjer sicer prevladuje suho kraško površje. Izvir kaže periodično slanost, ki je največja $\mathrm{v}$ poletnih meseciih. Z rešitvijo problema slanosti, bi izvir predstavljal potencialni vir pitne vode. Žal je, zaradi slabega upravljanja vodozbirnega območja, kvaliteta vode slaba. Območje Pantana je tipičen primer podrtega ravnovesja med naravnimi viri in človekovimi posegi v zaledju izvira. Zato morajo biti vsi bodoči ukrepi usmerjeni v rehabilitacijo in zaščito tega pomembnega kraškega območja. Članek predstavlja pregled trenutnega stanja izvira in predlagane ukrepe trajnostnega upravljanja s tem pomembnim kraškim ekosistemom. Za analizo faktorjev, ki vplivajo na okolje smo uporabili model DPSIR. Model omogoča pregledno analizo vpliva obremenitev, ki so posledica človekovih posegov v naravno okolje. Rezultati so pokazali, da je model DPSIR primerno orodje pri načrtovanju trajnostne razvojne strategije območja izvira Pantan. Nedvomno bo pri tem potrebno upoštevati veliko ranljivost krasa.
\end{abstract}

Ključne besede: brakični kraški izviri, celostno upravljanje, model DPSIR, Pantan, Hrvaška. 


\section{INTRODUCTION}

Pantan area is situated in the southwest of Kastela bay, between towns Split and Trogir (Fig. 1). It is the area of approximately 40 ha and presents inseparable unit consisting of Pantan spring, river course with surrounding swamp area and sea coast. The area presents green oasis in the mostly karstic area. Spring is a permanent and abundant coastal spring of ascending type. The opening of the spring is located at the elevation of 3 meters above sea level in the contact zone between the limestone and flysch layers while the catchments area is formed of highly permeable limestone rocks (Fritz et al., 1993). Spring discharge oscillates during the year. In summer period minimal discharge is $0,3 \mathrm{~m}^{3} / \mathrm{s}$, while in the winter period maximum discharge is $12 \mathrm{~m}^{3} / \mathrm{s}$. Flysch zone presents incomplete barrier towards the sea resulting with sea water intrusion into the spring aquifer (Bagarić 1973; Bonacci 1995). Therefore, the main characteristic of the spring is periodical salinity during the year with the highest salinity in summer months. Spring makes small lake Pantan with surface area from 35 to $60 \mathrm{~m}^{2}$ and depth of 13 meters. River Rika flows out of the lake to the sea and into the numeral brackish lateral channels that irrigate surrounding swamp area. Vegetation of the area is favorable for permanent or occasional residence of numeral bird species. Some of these species are unique and threatened of dieing out. Due to the variable ecological factors, temperature and salinity, life conditions in this biotope are very specific making favorable conditions for spawn and growth of particular fish and crab species. Therefore this small area presents unique ecological oasis and urgent protection from harmful human interventions is necessary.

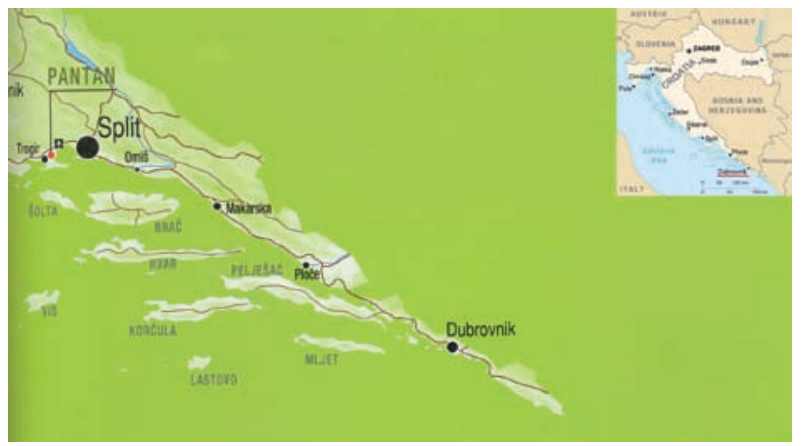

Fig.1: Pantan area location

From the ecological standpoint and according to the Environmental Protection Law, Pantan area presents unique swamp area in wide region and it is evaluated as a highly valuable environment. It should be mentioned that this area except natural values, has significant cul- tural-historical value. Mill situated in Pantan area according to its oldness and architecture presents valuable historical heritage (Figure 2). Furthermore, recent archeological investigations resulted with assumptions that archaeological remains in Pantan area date from the ancient time. If these excavations really date from the ancient time Pantan mill is unique example of mills built on ancient foundations. Unfortunately, this miniature cultural and nature reservation is almost unknown until today which is a great loss for this area.

Water from Pantan spring has never been used for water supply mainly because of the salinisation problem. Chloride concentration significantly changes during the year, and extreme values variate from $20 \mathrm{mg} / \mathrm{l}$ in January, and $10117 \mathrm{mg} / \mathrm{l}$ in August. In summer period water can be used only for the purposes of fish-farm since it is not sensitive to the chloride oscillations. Problem of sea water intrusion is widely spread in coastal karst areas of the world. This phenomena has been analyzed by many researchers for large number of locations (Arfib et al., 2000; Bonacci and Roje-Bonacci 1997; Breznik 1973; Breznik 1998; COST Action 621). Pantan spring is not an exception and extensive water investigations have been taken for the purpose of better understanding of complex hydrogeological conditions and finding solution for spring desalinization for the purpose of exploiting fresh water for the water supply (Bonacci et al., 1995; Komatina 1990; Mijatović 1984). Though these investigations gave some assumptions about spring functioning final solution of spring desalinization has never been achieved. Meanwhile, due to bed watershed management water quality of Pantan spring is permanently endangered. In present time, as the result of bad watershed management, salinity of the water is not the main problem comparing to the other water quality parameters.

Unfortunately through the past period many actions have been made that have contributed to the devastation of the whole Pantan area. Close to the spring main road is located. Area on the eastern border line of Pantan area is used as the waste disposal of town Trogir and it significantly contribute to the degradation of this area. On the west side new settlements are growing without any plans. In watershed area unplanned agriculture is developing. Pantan mill which have been well known in the history is due to careless mostly devastated. Fish farm is built without plan and in many ways contribute to the devastation of the area. Concrete bankment has been built making contrast to the surrounding area. Water loaded with fish food and dung is discharging from fish farm. Through the history many owners of the mill have changed and many changes on the historical mill building have been 


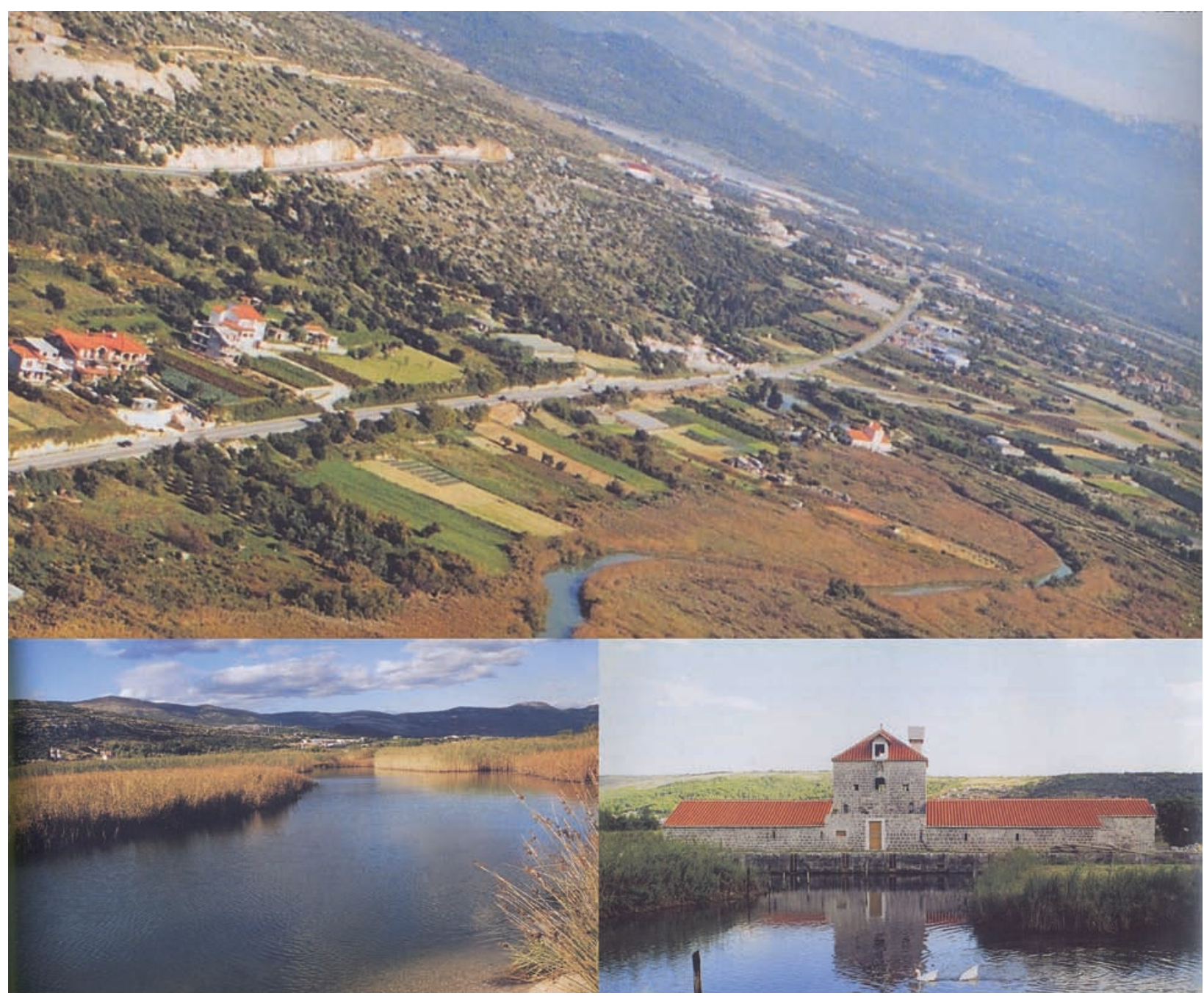

Fig.2: Pantan swamp area and Pantan Mill

made. All above mentioned actions are presenting an example of bad watershed management as well as bad care of reservation area and cultural heritage. All activities in watershed area of Pantan spring and Pantan reservation itself led to the significant devastation of this valuable natural and cultural-historical reservation.

It can be concluded that Pantan karst spring presents an example of not preserving balance between natural resources on karst and human interventions. Today water quality of Pantan spring is endangered which is mostly the result of the unplanned activities in watershed area and Pantan area. Human pressure and bad spatial planning made serious consequences on Pantan water quality. It is not possible to use water for the water supply but it is still possible to use it for the other purposes as for irrigation and fish-farm. Despite bad resource management even today Pantan has unique beauty and presents tourist potential due to its particular natural and historical values. Therefore all further activities taken in this area should not have the advantage over the environment protection and should be directed on protection of karstic watershed and Pantan area. Above all integral protection that will stop further unsuitable use of this area is necessary. In integral concept problem of karst vulnerability should be involved into the watershed management. This paper presents state of the Pantan spring, overview of recent resource management, as well as further necessary measures directed to the preservation and sustainability of this distinct karst ecosystem. 


\section{METHODS AND APPROACHES}

Prerequisite for accomplishing sustainable development of natural resources is integral approach - integrated resources management. One of the definitions of the integrated water resources management says that it is the process that promotes the co-ordinated development and management of water, land and related resources, in order to maximize the resultant economic and social welfare in and equitable manner without comprising the sustainability of vital ecosystems. Integral concept is particularly desirable and necessary in karst areas which are very sensitive and open to the pollution generated in the watershed area and therefore very vulnerable. Integrated environmental assessment is also defined as the interdisciplinary process of identification, analysis and appraisal of all relevant natural and human processes and their interactions, which determine both the current and future state of environmental quality, and resources, on appropriate spatial and temporal scales, thus facilitating the framing and implementation of policies and strategies (Stanners and Bordeau 1995). For the implementation of integrated assessment system approach is necessary. A system approach recognizes the individual components as well as the linkages between them, meaning that a disturbance at one point in the system will be translated to other parts of the system. System approach is clearly visible through DPSIR framework.

DPSIR framework is system approach that recognizes the linkages between the environment and the socioeconomic domains. Implementation of the DPSIR framework (Driving forces, Pressures, States, Impacts, Responses) is the basis for the efficient and transparent water resources management. Figure 3 presents general technical description of the framework which can be implemented not only on water resources but on any natural environment. It is causal framework for describing the interactions between society and the environment. It was made for the purpose of accomplishing the mission of the European Environmental Agency (EEA) which is 'to support sustainable development and to help achieve significant and measurable improvement in Europe's environment through the provision of timely, targeted, relevant and reliable information to policy-making agents and the public'. Indicators on environmental relevant issues provide information on the DPSIR elements. In its original form DPSIR framework is a general framework for organizing information about the state of the environment. It is a logical and a good way to structure data and information about the environment and information on different environmental problems. DPSIR framework is the basis for state-of-environment reports, consisting of sets of indicators each representing some parts of links within the framework. Furthermore, DPSIR has been adopted as a framework and policy tool to identify management options for a range of environmental options. The DPSIR framework assumes cause-effect relationships between interacting components of the social, economic and environmental system. Framework makes visible the links between the causes of environmental problems, their effects on the state of the environment and relevant societal responses. The DPSIR framework aims at focusing environmental reporting on a set of indicators that represent the different compartments of DPSIR. This reminds on holistic approach including an integrated assessment which is desirable in task of watershed management. DPSIR concept helps in understanding system behavior. It establishes the functional and structural relationships among major elements of the system to understand how the system operates. This framework provides rational and clear guideline for modeling of pressures derived from human activities on natural environment, and the way they are changing state of the environment. It can be concluded that DPSIR approach is a useful tool to shape a sustainable development strategy.

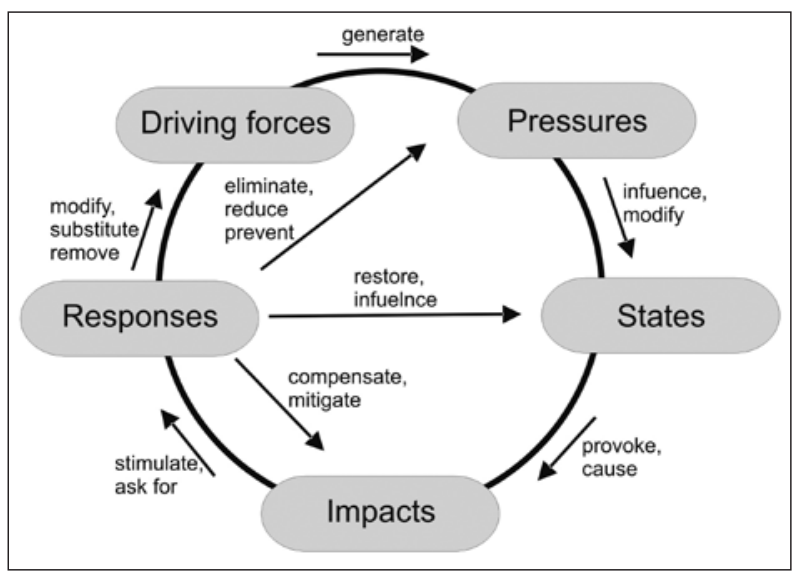

Fig. 3: The DPSIR model

Figure 3 shows interconnection between Driving forces of environmental changes (general: population, economy, land use, societal development; Sector specific: industry, agriculture, fisheries, transport, tourism, recreation), Pressures on the environment (soil emissions, water emissions, air emissions, waste, use of resources), State of the environment (water, soil, air), Impacts on population, economy, ecosystem (human health problems and other functions of the environment), Response of the society (environmental policies and measures). Human activities (Driving forces) generate the 'Pressures' on the environment, which in turn influence and modify 
'environmental conditions' (State) and therefore provoke and cause environmental problems - 'Impacts' on human beings, natural resources and materials. These problems stimulate and ask for 'Responses' and close the loop back to human activities and also led to policy actions. The Responses may be technical measures, affecting directly pressures or state, or policy instruments directed to the driving forces.

DPSIR framework offers a basis for analyzing the inter-related factors that impact on the environment. The aim of such an approach is (a) to be able to provide information on all of the different elements in a DPSIR chain, (b) to demonstrate their interconnectedness, (c) to estimate the effectiveness of Responses. There have been certain changes in philosophy of analysis specific element of the concept. In past, priority has largely been given to the Pressures, State and Impact. In future, increasing attention will be given to the Forces and Responses. This practically means making more active measures and less passive measures.
Successful implementation of the European Water Framework Directive which aims at improving water quality using an integrated management approach requires appropriate mathematical models and other tools to manage different phases of the planning procedure and to support decision making in various steps of the implementation process. Furthermore integration of these models is needed. DPSIR framework provides a basis to assure that proper tools will be available and selected for defined purposes. It is important to stress out that DPSIR concept helps in achieving transparent representation and understanding of the role of different models in the process of decision making. This practically means that in the place of each arrow (Figure 3) model can be placed showing the interaction between particular models.

In this paper DPSIR approach is used for presentation and evaluation of the seriousness of environment degradation as well as a useful tool to shape a sustainable development strategy for Pantan area.

\section{RESULTS}

Insight of the Pantan spring and state of the environment of the Pantan area is presented by the application of the DPSIR framework. Using this framework cause-effect analysis for the Pantan area is made. Figure 4 shows state of the environment of the Pantan area through the framework.

In case of Pantan spring significant number of driving forces is present in the watershed area and Pantan area showing that recent watershed management was very poor and inefficient. Settlements in watershed area are mostly built without any plans. Building was not controlled through the laws which are usually applied for the springs planned for water supply. For these springs sanitary protection zones are proposed which was not the case with Pantan spring. These settlements do not have sewage system but they dispose water directly to the ground. Through the karst channels in the underground this pollution is coming directly to the spring. Main road in the county is placed very close to the spring which is inadmissible from the point of water quality protection. Furthermore, large waste area of the town Trogir is in close vicinity. All driving forces which are above mentioned have the influence/pressure on quality of underground waters flowing to the spring as well as on the environment of the reservation area. This pressure influence and modify water quality of the spring as well as the water quality in the whole swamp area. As the result of above mentioned processes and interrelations is the spring water quality that does not comply standards of drinking water. Water usage for the fish farm is also endangered though these standards are less strict comparing to drinking water. Water quality in swamp area is also changed causing biotope changes. As the result of these changes dieing out of certain unique species is happening.

In integral management measures for achieving sustainable management need to be implemented. These measures are represented in DPSIR concept as responses which make influence on all elements of the concept (environmental, economic and social aspects). There is significant number of measures/responses that could be implemented for the purpose of improving present state and caused impacts. Above all better watershed management should be organized. Present state shows that in the past period watershed management did not have elements of integrated watershed management. Better strategy for reservation area exploitation and protection is necessary. In the past period there was no clear strategy for the usage of this area. First step in this direction is announcing this area as the protected area. These strategies for the watershed area and reservation area would help in preventing growing of driving forces. These measures present active protection measures that could stop pollution in its early start. Partly active measure is the prevention of watershed pollution through water purification directly on the source of pollution and before water dis- 


\begin{tabular}{|c|c|c|c|c|c|c|}
\hline Driving forces & \multirow[b]{2}{*}{$\rightarrow$} & Pressures & \multirow[b]{2}{*}{$\rightarrow$} & States & \multirow[b]{2}{*}{$\rightarrow$} & Impact \\
\hline $\begin{array}{l}\text { - Urbanization } \\
\text { - Waste disposals } \\
\text { - Roads } \\
\text { - Agricultural } \\
\text { production } \\
\text { - Interventions in the } \\
\text { reservation area } \\
\text { - Natural conditions: } \\
\text { sea-karst interaction }\end{array}$ & & $\begin{array}{l}\text { - Waste water } \\
\text { - Pollution emission } \\
\text { from roads } \\
\text { - Discharge of nutrients } \\
\text { from agricultural soils } \\
\text { - Devastation of } \\
\text { natural conditions in } \\
\text { reservation area } \\
\text { - Sea water intrusion }\end{array}$ & & $\begin{array}{l}\text { - Polluted spring water } \\
\text { - Changes of biotope } \\
\text { - Decrease of swamp } \\
\text { area } \\
\text { - Brackish spring water }\end{array}$ & & $\begin{array}{l}\text { - Inability of using } \\
\text { water for water } \\
\text { supply and other } \\
\text { purposes } \\
\text { - Loss of biodiversity in } \\
\text { swamp area }\end{array}$ \\
\hline \multicolumn{2}{|l|}{$\uparrow$} & $\uparrow$ & \multicolumn{3}{|c|}{$\uparrow$} & $\uparrow \downarrow$ \\
\hline \multicolumn{7}{|c|}{ Responses } \\
\hline \multicolumn{2}{|c|}{$\begin{array}{l}\text { - Watershed protection } \\
\text { - Sustainable management } \\
\text { strategy } \\
\text { - Better plans for reservation } \\
\text { usage } \\
\text { - Systen of issuing permissions } \\
\text { - Analyses of sea water } \\
\text { intrusion precesses }\end{array}$} & \multicolumn{2}{|l|}{$\begin{array}{l}\text { - Treatment of discharge } \\
\text { waters } \\
\text { - Diffuse pollution control } \\
\text { - Measure for area water } \\
\text { intrusion preservation }\end{array}$} & \multicolumn{2}{|c|}{$\begin{array}{l}\text { - Treatment of spring water } \\
\text { - Water desalinization } \\
\text { - Conservation and restoration }\end{array}$} & $\begin{array}{l}\text { - Planning water using } \\
\text { according to the } \\
\text { present water quality }\end{array}$ \\
\hline
\end{tabular}

Fig.4: The DPSIR model of the Pantan area

charging into the underground. Responses that eliminate and reduce pressures would be very efficient measure. Firstly this means building of sewage systems as well as building waste water treatment plants. Diffuse pollution control could significantly contribute to the water quality improvement. Since present state is already degraded measures that will influence and restore the present state would be necessary. These measures include treatment of spring water as well as measures with the purpose of the restoration of natural conditions in the swamp area. Last mentioned measure presents totally passive measure that compensates and mitigates the impacts. These are the measures directed to the consequences of the bad watershed management.

There is the other set of indicators included in DPSIR scheme originated not from the human activities but from natural conditions. They present the problem of sea water intrusion. In this problem driving forces present closeness to the sea and natural conditions of karst that make underground aquifer open to the sea intrusion. Sea water intrusion process presents the pressure. Resulting unwanted impact is the inability of using brackish water for water supply. Responses to the sea impact can be made on all levels of presented DPSIR scheme. First step is directed to analyses and better understanding of driving forces, in this case sea influence on fresh aquifer, and it presents analysis of sea water intrusion process. This presumes understanding of hydrogeological conditions in the underground that make sea intrusion process pos- sible. Knowing these conditions is the prerequisite for making adequate technical interventions for the purpose of preventing sea water intrusion. These interventions result with changing of the spring water state meaning that spring water will not be brackish any more. Possible solution is also the one that influence the impact which means changes of quality of brackish spring water. This means desalinization process but it remains a relatively expensive measure.

Presentation of Pantan area through DPSIR concept shows very clear picture of the present state and clear picture of possible measures that can be implemented as well as their influence on certain elements of the concept. Clear presentation of all elements and their interactions is prerequisite for efficient sustainable management of Pantan area. 


\section{DISCUSSION AND CONCLUSION}

Pantan swamp area gives significant biological and ecological value to the surrounding mostly karstic dry area and contributes to the variability of that uniform area. It presents unique natural reservation, but unfortunately it also presents the area where preservation of brittle balance between natural resources in karst and human interventions has not been achieved. Pantan is the example of degradation of natural environment, as the result of the unsatisfactory interventions in close and wide area. Such treatment is not adequate for this area. This swamp area with significant natural and environmental values, in combination with valuable cultural-historical heritage should be evaluated as valuable location together with town Trogir, which is announced as UNESCO town.

In this paper DPSIR framework is used for organizing information about the state of the environment as well as for organizing management system following the integration principle (environmental, economic and social aspects). DPSIR approach is a useful tool to shape a sustainable development strategy and it is officially accepted as the basis for further adoption and development for the WFD purposes, since many of the tasks required by the Directive refer directly to the elements of the DPSIR framework. DPSIR methodology is applied to this area for the assessment of environmental conditions, elaboration of management plans and design of specific restoration/conservation actions to be carried out.

Presentation of DPSIR concept for Pantan shows that in previous period there were no elements of system approach in the management of environmental resources in this area. Sustainable development does not exist and it is visible that human pressure on natural resources has been made without hesitation about consequences. DPSIR concept clearly shows that existing state can be enhanced through the active measures for prevention of further devastation of the area as well as passive measures for the rehabilitation of the area. Regarding problem of sea water intrusion scientific research projects are necessary.

It is important to notice that in the past period natural and cultural-historical potentials have never been sufficiently estimated which can explain lack of watershed management. It is the question if this zone will be named as protected area or it will be simply ignored and subjected to all other needs such as unplanned growth of settlements in watershed area, as development of fish farm, building coastal swimming zone and other. Fortunately in recent time certain improvements in treatment of this area have been made. According to the Nature protection law in year 2000 Pantan area is named as special reservation since it has particular importance for preserving biological diversities. Idea of using this area for the education-touristic purposes is growing. New owner of the mill is planning to build small hydro-electric power plant and solar system, renovate mill and through all this give new values to natural and cultural heritage of the area.

Prerequisite for above mentioned plans is adequate regional planning of resource exploitation in the whole watershed area of Pantan spring. Analysis of DPSIR concept clearly shows that different Responses influence the elements of the concept. Through response variables it is believed to improve the situation with regard to sustainability. Basis for the further development of this area should be protection of natural characteristics which has its foothold in legislation but it is usually understated and no implemented. This includes adequately regional planning of watershed area and resources exploitation. Through the definition of the regional plans it is necessary to implement regulations that will define preservation of natural conditions and provide their protection. Furthermore, integral project of the rehabilitation of whole area is needed. It is important not to make any actions that could result with changes in water regime since that would result with changes in vegetations and therefore changes in biotope. Since this location is very small it is necessary to estimate capacity for tourist reception visitors to prevent devastation of the area. In order to preserve present state and make certain improvements it is necessary to encourage establishment of natural conditions. In swamp area many activities as devastation of canes, catch of shells and fish should be stopped. In the watershed area, which is very vulnerable karst area, unplanned construction, intensive agriculture and waste dumps should be stopped. All these responses/measures should be controlled through DPSIR framework which is adequate tool to shape and implement sustainable development strategy for the Pantan area. 


\section{REFERENCES}

Arfib B., de Marsily G., Ganoulis J., 2000: Pollution by seawater intrusion into a karst system: new research in the case of the Almyros source (Heraklio, Crete, Greece). Acta Carsologica, 29 (1.1), 15-31.

Bagarić, I., 1973: Prilog rješavanju problema iskorištenja zaslanjenih voda priobalnog i kraškog vrela Pantan kod Trogira.- Saopštenja Zavoda za hidrotehniku Građevinskog fakulteta u Sarajevu. 13, 1-18.

Bonacci, O., 1995: Brackish karst spring Pantan.- Acta Carsologica. XXIV, 97-107.

Bonacci, O., Fritz, F., Denić-Jukić, V., 1995: Hydrogeology of Slanac Spring.- Hydrogeology Journal. 3(3), 31-40.

Bonacci O., Roje-Bonacci T., 1997: Sea water intrusion in coastal karst springs: example of the Blaž Spring, Journal-des Sciences Hydrologiques, 42(1), 89-100.

Breznik, M., 1973: Nastanak zaslanjenih kraških izvora in njihova sanacija. Geologija, The origin of brackish karstic springs and their development.- Geologija Razprave in poročila, Ljubljana. 16. knjiga, 83-186.
Breznik, M., 1998: Storage Reservoirs and Deep Wells in Karst Regions. A.A. Balkema, Rotterdam, Brookfield

COST Action 621. Ground water management of coastal karstic aquifers.- Final report. EUR 21366.

Fritz, F., Pavičić, A., Renić, A., 1993: Hydrogeology of the Hinterland of Šibenik and Trogir.- Geologia Croatica. 46(2), 291-306.

Komatina, M., 1990: Problemi zahvatanja podzemnih voda u karstu.- Voda i sanitarna tehnika. XX(1)

Mijatović, B., 1984: Hydrology of the Dinaric Karst. International Association of Hydrogeologist. Volume 4. 115-142.

Stanners, D. and Bordeau, P (eds.), 1995: Europe's Environment: The Dobris Assessment. European Environment Agency, Copenhagen. 